TINJAUAN YURIDIS TERHADAP PERCERAIAN BAGI PEGAWAI NEGERI SIPIL

Oleh :

\author{
I Made Gede Adi Palguna., S.H.,M.H \\ Program Studi, Fakultas Hukum Universitas Mahendradatta \\ Jl. Ken Arok No. 12 , Peguyangan Denpasar Utara, Bali 80115. \\ (adipalguna93@gmail.com)
}

\begin{abstract}
Abstrak, Pernikahan adalah ikatan batin dan luar laki-laki dan perempuan sebagai suami dan istri dengan tujuan membentuk keluarga atau rumah tangga yang bahagia dan kekal berdasarkan pada satu keilahian tertinggi. Perceraian adalah eleminasi perkawinan dengan keputusan hakim atau tuntutan salah satu pihak dalam perkawinan tersebut. Pegawai negeri sipil yang akan melakukan perceraian atau sertifikat terlebih dahulu dari pejabat. Permasalahan yang diangkat dalam penelitian ini adalah bagaimana prosedur yang harus diikuti bagi PNS untuk mendapatkan izin perceraian dan bagaimana konsekuensi hukum yang timbul dari perceraian bagi PNS. Penelitian ini adalah hukum normatif, pendekatan konseptual dan pendekatan hukum. Bahan hukum yang digunakan adalah bahan hukum primer dan bahan hukum sekunder. Pengumpulan materi hukum dilakukan dengan mengutip, merangkum, dan memberikan ulasan serta dokumentasi bahan hukum utama. Analisis bahan hukum yang digunakan adalah mengumpulkan bahan hukum yang kemudian dianalisis secara sistematis. Prosedur yang harus diikuti dalam memperoleh izin perceraian untuk pegawai negeri adalah harus memiliki izin dari atasannya kepada mereka yang berganti pegawai negeri sipil. Lingkungan, masingmasing yang pertama kali diupayakan rekonsiliasi antara suami dan istri, jika tidak berhasil, maka petugas meminta keputusan atas permintaan lisensi perceraian dengan mempertimbangkan alasan alasannya. Konsekuensi hukum yang timbul dari perceraian kepada pegawai negeri adalah karena hukum suami-istri adalah konsekuensi hukum bagi anak-anak yang berbagi hak asuh atas anak-anak sebagai akibat dari harta perkawinan, yaitu pembagian harta bersama atau harta bersama.
\end{abstract}

Kata kunci: perceraian, PNS

Abstract, Marriage is a bond the inner and outer man and woman as husband and wife with the aim of forming a family or household that is happy and eternal based on one supreme divinity. Divorce is the elemination of the marriage with the decision of the judge or the demands of one of the parties to the marriage.Civil servants who will do the divorce or certificate in advance of the official. Issues raised in this research is how the procedure to be followed for civil servants to obtain a permit divorce and how the legal consequences arising from divorce for civil servants. This study is the legal normative, conceptual approach and approach the laws. Legal materials used are the primary legal material and secondary legal materials. Collection of legal material is done by quoting, summarizing and provides reviews and documentation of primary legal materials. Analysis of legal material used are collecting legal material which is then analyzed systematically. Procedure to be followed in obtaining permits divorce for civil servants is a must have permission from his superiors to those in change of civil servants. Environment, respectively the first to be attempted reconciliation between the husband and wife, if not succesful, then the officer tok the decision at the request of the divorce license with consider the reason the reason. Legal consequences arising from divorce to civil servants is due to the law of the husband and wife are legal consequences for children are sharing custody of children as a result of marital property, namely the division of joint property or possessions together.

Keywords: divorce, civil servants 


\subsection{Latar Belakang}

Dalam masalah perkawinan dan perceraian bagi Pegawai Negeri Sipil diberlakukan ketentuan khusus dalam proses perkawinan dan perceraian karena Pegawai Negeri Sipil adalah unsur aparatur Negara, abdi Negara dan abdi masyarakat, dimana mereka ini dalam kedudukannya terikat dengan sumpah dan janjinya selaku Pegawai Negeri Sipil dan ketentuan perundang-undangan yang berlaku. Bagi Pegawai Negeri Sipil pria yang akan beristri lebih dari seorang, wajib memperoleh izin tertulis lebih dahulu dari Pejabat. Bagi Pegawai Negeri Sipil wanita tidak diizinkan menjadi isteri kedua/ketiga/keempat. Seorang wanita yang berkedudukan sebagai isteri kedua/ketiga/keempat dilarang menjadi Pegawai Negeri Sipil. Dalam PP NO. 10 tahun 1983 tentang izin perkawinan dan perceraian bagi Pegawai Negeri Sipil dinyatakan tidak diperbolehkan seorang Pegawai Negeri Sipil hidup bersama-sama dengan pasangannya diluar ikatan perkawinan yang sah.

\subsection{Rumusan Masalah}

1. Bagaimana prosedur yang harus ditempuh bagi Pegawai Negeri Sipil untuk memperoleh ijin perceraian?

2. Bagaimana akibat hukum yang timbul dari perceraian bagi Pegawai Negeri Sipil ?

\subsection{Tujuan Penelitian}

\subsubsection{Tujuan Umum}

1. Untuk perkembangan dan pengetahuan di bidang Hukum Khususnya bagi Mahasiawa maupun bagi masyarakat pada umumnya.

2. Untuk melaksanakan Tri Dharma Perguruan tinggi dibidang penelitian yang di lakukan oleh Dosen

\subsubsection{Tujuan Khusus}

1. Untuk menegetahui prosedur yang harus ditempuh bagi Pegawai Negeri Sipil untuk memperoleh ijin perceraian

2. Untuk mengetahui akibat hukum yang timbul dari perceraian bagi Pegawai Negeri Sipil

\subsection{Tinjauan Pustaka}

a. Tata cara atau prosedur yang harus di tempuh adalah harus ada ijin dari atasannya yaitu mereka yang membawahi Pegawai Negeri Sipil dalam lingkungannya masingmasing, maka terlebih dahulu haruslah berusaha merukunkan kembali suami istri, kalau tidak berhasil, maka pejabat mengambil keputusan atas permintaan ijin perceraian itu dengan mempertimbangkan alasan-alasan.

b. Bagi Pegawai Negeri Sipil, jika terjadi perceraian maka akibat yang timbul adalah dijatuhinya dua sanksi yaitu baik berupa sanksi adminitratif berupa pemberhentian dengan hormat bagi Pegawai Negeri Sipil yang bersangkutan dan dijatuhi sanksi hukum (Yuridis) yang berupa pemutusan peceraian oleh Pengadilan.

\subsection{Metode Penelitian}

Dalam memperoleh, mengumpulkan dan menganalisis setiap data/bahan hukum yang bersifat ilmiah, memerlukan metode dengan tujuan agar suatu karya ilmiah mempunyai susunan yang sistematis, terarah dan konsisten. Adapun metode penelitian ini adalah metode penelitian Normatif yang menggunakan pendekatan konsepsional dan pendekatan perundang-undangan. Bahan Hukum yang dipergunakan adalah bahan 
hukum primer dan bahan hukum skunder. Pengumpulan bahan hukum dilakukan dengan cara mengutip, meringkas, serta memberikan ulasan-ulasan dan dokumentasi bahan-bahan hukum primer. Analisi Bahan Hukum yang dipergunakan adalah mengumpulkan bahan Hukum yang kemudian dianalisis secara sistematis.

\subsection{Hasil Dan Pembahasan}

\subsubsection{Prosedur dan Akibat Hukum} Terhadap Suami dan Istri dalam izin Cerai

Prosedur yang harus ditempuh memperoleh ijin perceraian bagi Pegawai Negeri Sipil adalah harus ada ijin dari atasannya yaitu mereka yang membawahi Pegawai Negeri Sipil dalam lingkungannya masing-masing, maka terlebih dahulu haruslah berusaha merukunkan kembali suami istri, kalau tidak berhasil, maka pejabat mengambil keputusan atas permintaan ijin perceraian itu dengan mempertimbangkan alasan-alasan. Akibat Hukum perceraian bagi Suami dan Isteri menurut Putusan Pengadilan Negeri Denpasar Nomor : 579/Pdt.G/2011/PN.Dps. yaitu :

1. Akbat Hukum terhadap Suami yaitu :

a. Mengabulkan gugatan penggugat seluruhnya.

b. Menyatakan Perkawinan antara penggugat dengan Tergugat yang dilangsungkan pada tanggal 31 desember 1997 secara Agama Hindu yang dilangsungkan di kelurahan Kaliuntu dan perkawinan tersebut telah didaftarkan di Kantor catatan Sipil Kabupaten Singaraja dengan Nomor : 158/WNI/BLL/1998 tertangal 18 Juli 1998 putus Karena Perceraian.
2. Akibat Hukum terhadap Isteri yaitu :

a. Mengabulkan gugatan penggugat seluruhnya.

b. Menyatakan Perkawinan antara penggugat dengan Tergugat yang dilangsungkan pada tanggal 31 desember 1997 secara Agama Hindu yang dilangsungkan di kelurahan Kaliuntu dan perkawinan tersebut telah didaftarkan di Kantor catatan Sipil Kabupaten Singaraja dengan Nomor : 158/WNI/BLL/1998 tertangal 18 Juli 1998 putus Karena Perceraian.

\subsubsection{Akibat Hukum Terhadap Harta Perkawinan}

Dalam Kasus yang diangkat tidak terdapat dicantumkan dalam Putusan Pengadilan Negeri Denpasar dengan NOMOR : 579/pdt.G/2011/PN.Dps. mengenai harta bersama, karena dalam kasus perceraian ini tidak ada pihak yang mempermasalahkan atau menuntut mengenai harta bersama, dikarenakan sudah lama pihak tergugat dan penggugat pisah ranjang atau tidak hidup bersama-sama lagi, jadi kedua belah pihak hidup masing-masing dengan harta yang dimiliki masing-masing, dan dari hubungan perkawinan kedua belah pihak tidak memiliki harta bersama yang ternilai cukup besar jika dinilai dengan materiil atau uang. Maka dalam kasus ini tidak terjadi pembagian harta bersama atau harta gono-gini.

\subsection{SIMPULAN DAN SARAN}

\subsubsection{Simpulan}

Dari uraian pembahasan yang penulis bahas diatas maka penulis dapat menarik beberapa kesimpulan yaitu : 
1. Prosedur yang harus ditempuh memperoleh ijin perceraian bagi Pegawai Negeri Sipil adalah harus ada ijin dari atasannya yaitu mereka yang membawahi Pegawai Negeri Sipil dalam lingkungannya masing-masing, maka terlebih dahulu haruslah berusaha merukunkan kembali suami istri, kalau tidak berhasil, maka pejabat mengambil keputusan atas permintaan ijin perceraian itu dengan mempertimbangkan alasanalasan.

2. Akibat Hukum yang ditimbulkan dari perceraian bagi Pegawai Negeri Sipil yaitu :

a. Akbiat Hukum terhadap Suami dan Istri Akibat Hukum yang di timbulkan terhadap suami dan istri adalah Putusnya perkawinan oleh Hakim dengan didasari oleh gugatan penggugat yang di sertai alasan-alasan penggugat. Didalam putusnya perkawinan karena Perceraian tentunya terdapat pembagian harta bersama dan Hak asuh Anak. Selain daripada itu apabila perceraian di gugat oleh suami, maka suami wajib menafkahi bekas istrinya, selama bekas istrinya belum melangsungkan perkawinan kembali, dan apabila perceraian tersebut di gugat oleh istri, maka bekas istri tidak berhak mendapatkan nafkah dari bekas suaminya.

b. Akibat Hukum terhadap Harta Bersama Mengenai akibat Hukum terhadap Harta Bersama belum di atur secara khusus didalam Undang-Undang Perkawinan, dimana dalam Pasal 37 UU perkawinan cuma menyatakan bahwa Harta Bersama diatur dalam Hukum Adat dan Agamanya masing-masing, tetapi dalam pasal 128 KUHPerdata menyatakan harta bersama dibagi dua antara bekas suami dan bekas istri.

\subsection{2 .Saran}

Masalah perceraian menyangkut beberapa aspek yaitu aspek sosial, aspek agama dan aspek hukum disamping biaya hidup terhadap Pegawai Negeri Sipil, maupun istri dan anak-anaknya, maka pada kesempatan ini penulis menyarankan kepada semua Pegawai Negeri Sipil dan anak-anaknya, maka pada kesempatan ini penulis menyarankan kepada Pegawai Negeri Sipil yang ingin melakukan penceraian, terlebih dahulu mempertimbangkan dari segala seginya.

a. Kepada pejabat yang memberi ijin perceraian, hendaknya lebih berhati-hati menangani masalah ini yaitu dengan jalan melihat secara langsung tentang alasan yang dipergunakan oleh Pegawai Negeri Sipil tersebut, sehingga apa yang dipertimbangkan tidak secara sepihak. Dan merupakan suatu keaadan yang tidak dapat dihindari untuk memenuhi pemberian ijin tersebut.

\section{DAFTAR BACAAN}

Ahmad Ghufron, Hukum Kepegawaian Di Indonesia, Rineka Cipta, cetakan pertama, Jakarta.

Amirudin \& Zainal Asikin, Pengantar Metode Penelitian Hukum,Cetakan Pertama, Raja Grafindo Persada,Jakarta.

A.W. Widjaja, Adminitrasi Kepegawaian, Rajawali, Jakarta.

Bambang Waluyo, Penelitian Hukum Dalam Praktek, Sinar Grafika, Jakarta. 
Djamil latif, Aneka Hukum Perceraian di Indonesia,Cetakan Pertama,Ghalia Indonesia, Jakarta.

Happy Susanto, Pembagian Harta Gono-Gini saat Terjadinya Perceraian, Redaksi, Cetakan ketiga, Jakarta.

Hilman Hadi Kusuma, Hukum Perkawinan Adat, Citra Aditya Bakti,Cetakan Keempat, Bandung.

J.B. Daliyo, Pengantar Ilmu Hukum, Gramedia Pustaka Utama, Jakarta.

Mukti Arto,Praktek Perkara Perdata pada Pengadilan Agama, Pustaka Pelajar,Yogyakarta.

Munir Fuadi, Konsep Hukum perdata, Cetakan pertama, Raja Grafindo Persada, Jakarta.

Musanef, Manajemen Kepegawaian di Indonesia, Gunung Agung, Jakarta.

Peter Mahmud Marzuki, Penelitian Hukum, Prenada Media Group, Jakarta.

Salim HS, Pengantar Hukum Perdata Tertulis $(B W)$, Cetakan Pertama, Sinar Grafika,Jakarta.

Soedharyo Soimin, Hukum Orang dan Keluarg, cetakan pertama, Sinar Grafika, Jakarta.

Soetojo Prawirohamidjojo dan asis safioedin, Hukum Orang dan Keluarga, Alumni Bandung.

Sri Hartini, Setiajeng Kadarsih dan Tedi Sudrajat., Hukum Kepegawaian Di
Indonesia, cetakan kedua, Sinar Grafika, Jakarta.

Subekti, Perbandingan Hukum Perdata, Cetakan Keenam belas, Pradnya Paramita, Jakarta.

Sudarsono, Hukum perkawinan Nasional, cetakan pertama, Rineka Cipta, Jakarta.

Taufiqurrohman Syahuri, Legislasi Hukum Perkawinan Di Indonesia, Edisi pertama, Cetakan Pertama, Fajar Interpratama Mandiri, Jakarta.

Tolib Setiady,Intisari Hukum Adat Indonesia dalam kajian kepustakaan, Alfabeta, Bandung.

Kitab Undang-Undang Hukum Perdata

Undang-Undang Nomor. 1 Tahun 1974 Tentang Perkawinan

Undang-Undang Nomor 43 Tahun 1999 Tentang Perubahan UU Nomor 8 Tahun 1974 Tentang Pokok-Pokok Kepegawaian

Peraturan Pemerintah Nomor 10 tahun 1983 Tentang Izin Perkawinan dan Perceraian bagi Pegawai Negeri Sipil

Peraturan Pemerintah Nomor. 45 tahun 1990 Tentang Perubahan atas PP. No. 10 tahun 1983 Tentang izin Perkawinan dan Perceraian Bagi Pegawai Negeri Sipil

Peraturan Pemerintah Nomor 53 Tahun 2010 tentang disiplin Pegawai Negeri Sipil

Surat Edaran Kepala BAKN Nomor 08/SE/1983 Tentang Ijin Perkawinan dan Perceraian bagi Pegawai Negeri Sipil

http://sharingdisini.com/2013/06/18/faktorpenyebab-perceraian-yang-sering terjadi/ (Accessed : 2014, November 6) 